\title{
IMPACT OF GREEN FORAGES IN SPRING, IN THE STEPPE REGIONS OF TIARET "CHEHAIMA AND NAIMA", ON THE FATTY ACID COMPOSITION OF THE "BICEPS FEMORIS" MUSCLE OF LAMBS
}

\author{
Hocine Fadlallah Rabah ${ }^{1, *}$, Abdellatif Niar ${ }^{2}$, Benchohra Maamar ${ }^{3}$, Mohamed Azzaoui $^{3}$, \\ Mohamed Belabbes ${ }^{4}$, Belgacem Nouar ${ }^{3}$, Mohamed Amine Aissa ${ }^{3}$, Hicham Berrabah ${ }^{3}$ \\ ${ }^{1}$ Laboratory of Agro-Biotechnology and Nutrition in Semi-arid Zones, Faculty of Nature and Life \\ Sciences, Ibn Khaldoun University of Tiaret, Tiaret 14000, Algeria \\ ${ }^{2}$ Farm Animal Reproduction Laboratory, Institute of Veterinary Sciences, Ibn Khaldoun \\ University of Tiaret, Tiaret 14000, Algeria \\ ${ }^{3}$ Ibn Khaldoun University of Tiaret, Tiaret 14000, Algeria \\ ${ }^{4}$ Laboratories of Sciences and Techniques in Animal Production, BP 188, 27000, University \\ of Mostaganem, Algeria
}

\begin{abstract}
This work aimed to assess the impact of a diet based on green pastures of steppe rangelands and another based on a concentrate diet, on the composition of the intramuscular lipid fraction of different sections of the biceps femoral muscle of lambs, in two regions of the wilaya of Tiaret, in winter and in spring. The biceps femoral muscle sample collection came from 20 different lamb carcasses (10 samples for each of our two study regions, with 05 samples for each season). These samples were taken on different occasions in large butcher shops. Total SFA content in both regions shows dominance in lambs from the regimen concentrate, that $C$ 16: 0 and $C$ 18: 0 are the most dominant. There is no remarkable difference in total MUFA content, and on individual monounsaturated FA, between the two regimens. In both regions, the most dominant FAs in the intramuscular lipid fraction of pasture lambs are C18: $3 n 3$ followed by C18: $2 n 6$ cis-9, C20: 4n6, C20: 5n3, and C22: 6n3, compared to those from concentrate regimen; however, lambs from Chehaima concentrate regimen had the most dominant FA in their intramuscular fat, C18: 3n6 followed by C20: 4n6, compared to those from pastures of Naima. The values of the ratio $n-6 / n$-3 correspond to the nutritional recommendations. The feed ratio $\Sigma P U F A$ / $\Sigma S F A$ of lambs from pastures in the Chehaima region is the only one that corresponds to the desired value. Based on this research, it is concluded that lambs that have grazed grass in steppe rangelands have the richest meat in omega 3, which is more desirable and benefits for human health.
\end{abstract}

Keywords: Concentrate, fatty acids, grazing, lambs.

\section{INTRODUCTION}

In response to the rapidly increasing demand for lamb meat by the modern consumer, the current research is more interested now in improving the quality of the meat, often from lambs of green pastures. These meats are rich in polyunsaturated fatty acids (PUFA), and which present relatively simple production processes. Our previous study indicated that the nature of the diet is an essential factor that influences the composition of intramuscular fatty acids (FA) in lambs, whose family FAs $\mathrm{n} 3$ are more representative in those fed on steppe plants (Rabah et al., 2019), other studies also 
confirm the influence of diet on FA (Díaz et al., 2005; Ružić-Muslić, 2012), however, other intrinsic and extrinsic factors may influence and be responsible for the difference in FA such as sex, age, type of breeding, transport to the slaughterhouse, conservation of meat (De Smet et al., 2003 ; Amin and Mao, 2020). Currently, many ruminant breeders tend to modify their feeding practices by reducing the diet based on concentrate, and are now moving more and more to pasture grass which confers little fat in the ruminant carcass compared to that based on concentrate (Daley et al., 2010). Also, the problems associated with the use of concentrated feed in the diet of lambs, such as the increase in the content of saturated fatty acids (SFA) and cholesterol in meat, that causes diseases in humans, as chronic diseases such as cardiovascular disease, which interfere with insulin absorption and tumor carcinogenesis (Klir et al., 2012), An increased interest in rising the grass ratio in lamb feed (Prache et al., 2019). Other studies have shown that the meat of pasture lambs is an essential source of FA of the PUFA family n-3, and which has a lower fat content in the carcass, and with a lower content of SFA, unlike meat from those from the concentrated feeds (Jutzeler van Wijlen and Colombani, 2010; Ponnampalam et al., 2018). Reducing the intake of SFA and increasing the intake of PUFA-n3, especially long chain polyunsaturated fatty acids (PUFALC), are recommended by epidemiologists (Dias et al., 2017; Saini et Keum., 2018). The influence of different types of diets on the individual FA content of lamb meat has been the subject of several studies (Nguyen et al., 2018; Pannier et al., 2018). Pastures, especially with young plants are characterized by low fiber content and supplied to ruminants a high amount of linolenic acid (C18: $3 \mathrm{n}-3)$ which helps to increase the content of conjugated linoleic acid (CLA) and its precursor, the vaccenic acid (18: 1 trans-11); the following biohydrogenation in the rumen by microbial action, C18: 3n-3 (ALA) and linoleic acid (C18: 2n-6) (LA) from forage plants are converted into oleic acid (18: 1), the precursor of the synthesis of CLA which is increasingly taken into consideration by nutritionists, because it contributes to the good health of the human being (Angeles-Hernandez et al., 2020 ; Budimir et al., 2020), however, these PUFAs contained in forage plants are exposed to several factors that can reduce their levels, such as botanical composition, seasonal variations in climate, and the vegetative stage of the plant (Cividini et al., 2018). In contrast, the animals fed the concentrate show a low content of PUFA, in particular, PUFA n-3 (Nuernberg et al., 2005). It seems of our knowledge, that there are only a few studies that have reported the content and composition of intramuscular FA in lambs that grazed in steppe rangelands (Berrighi et al., 2017; Rabah et al., 2019), which makes it very important to provide scientific evidence serving to discriminate diets that may improve the performance quality of lamb meat. This study aimed to study the effects of grazing in steppe rangelands on the $\mathrm{AF}$ profile of lamb meat.

\section{MATERIALS AND METHODS}

The lambs are traditionally reared in the pastures of the steppe, located in the two regions of Chehaima and Naima (Tiaret steppe), during the spring period and are supplemented in winter. During the period from March to the end of June, and then during the period from December until the end of February, lambs are feeding with concentrate in the barns. Someones have reported that the concentrated feed is made up primarily of barley (Luciano et al., 2012). Biceps femoris muscle samples collection was done from 20 different lamb carcasses (10 samples for each region, and with 5 samples for each season), were collected on different occasions from various large butcher shops of the Tiaret region. Before starting the biochemical analyzes to quantify and identify the methyl esters of fatty acids of the intramuscular lipid fraction by transesterification, by mixing internal standard 1, 2, 3-tripentadecanoylglycerol in a solution of boron trifluoride to $20 \%$ in methanol (Tor 
et al., 2005), the collected samples were first of all lyophilized and then homogenized. The gas chromatography used is equipped by an oven at a temperature of 150 to $225^{\circ} \mathrm{C}$. The fatty acids were separated by a capillary column SP2330 of $30 \mathrm{~m} * 0.25 \mathrm{~mm}$ (Supelco, Tres Cantos, Madrid).

\section{ANALYSES STATISTICS}

Statistical analyzes were carried out in order to treat the intramuscular fatty acids of the biceps femoris muscles which characterize the sheep of the different diets, for this, an ANOVA test was carried out, followed by a Tukey Post Hoc test.

\section{RESULTS AND DISCUSSIONS}

The intramuscular AFs of the present study, as shown in the table, are of 24 fatty acids $(\mathrm{C} 10: 0, \mathrm{C}$ 12 :0, C 14 :0, C 15 :0, C 16 :0, C 17 :0, C 18 :0, C 20 :0, C 24 :0, C14 :1, C16 :1, C18 :1 cis-11, C18 :1 cis-9, C18 :1 trans-9, C20 :1, C18 :2n6 cis-9, C18 :2n6 trans-9, C18 :3n6, C18 :3n3, C20 :2n6, C20 :3n6, C20 :4n6, C20 :5n3, C22 :6n3) (Table.1). These fatty acids were detected from the two diets, and each region has significant differences in FA composition. The individual AFs obtained from the grass-fed lambs had lower concentrations than those from lambs feed with the concentrate, of which the most dominant in Chehaima region was the stearic acid (C 18: 0) when compared with the others lambs from the pasture of Naima region, while, the most dominant in Naima region was the palmitic acid (C 16: 0), compared to those from pastures in the same region, these two AFs constitute the largest part of the lamb meat fatty acids, respectively with $18.1 \%$ and $22.2 \%$ (Wood et al., 2004).

Table 1: Mean and standard deviation of mean of Intramuscular fat content of the Biceps Femoris muscle of lambs (mg/g fatty acids)

\begin{tabular}{|c|c|c|c|c|c|c|c|c|}
\hline \multirow[t]{2}{*}{ Fatty acids } & \multicolumn{2}{|l|}{ Chehaima } & \multicolumn{2}{|l|}{ Naima } & \multicolumn{4}{|c|}{ Signification } \\
\hline & Grazing & Concentrate & Grazing & Concentrate & $\begin{array}{l}\text { PCh vs } \\
\text { CCh }\end{array}$ & $\begin{array}{l}\text { PCh vs } \\
\text { CN }\end{array}$ & $\begin{array}{l}\text { PN } \\
\text { vsNC }\end{array}$ & $\begin{array}{l}\mathrm{PN} \text { vs } \\
\mathrm{CCh}\end{array}$ \\
\hline C $10: 0$ & $0.03 \pm 0.01$ & $0.05 \pm 0.01$ & $0.1 \pm 0.00$ & $0.07 \pm 0.00$ & $* *$ & $* * *$ & $* * *$ & *** \\
\hline C $12: 0$ & $\begin{array}{l}0.23 \pm \\
0.09\end{array}$ & $0.47 \pm 0.17$ & $2.46 \pm 1.68$ & $1.93 \pm 1.34$ & - & - & - & * \\
\hline C $14: 0$ & $0.2 \pm 0.11$ & $0.27 \pm 0.08$ & $0.95 \pm 0.51$ & $1.78 \pm 0.39$ & - & $* * *$ & $* * *$ & $* *$ \\
\hline C $15: 0$ & $0.22 \pm 0.08$ & $0.11 \pm 0.07$ & $0.19 \pm 0.01$ & $0.23 \pm 0.02$ & $*$ & - & - & - \\
\hline C $16: 0$ & $8.34 \pm 3.18$ & $13.33 \pm 2.17$ & $5.65 \pm 3.45$ & $11.23 \pm 1.68$ & - & - & * & ** \\
\hline C $17: 0$ & $1.08 \pm 0.40$ & $1.74 \pm 0.61$ & $0.76 \pm 0.06$ & $1.03 \pm 0.06$ & $*$ & - & - & *** \\
\hline C $18: 0$ & $6.17 \pm 3.87$ & $9.28 \pm 1.18$ & $3.82 \pm 3.05$ & $7.78 \pm 1.03$ & - & - & - & $* *$ \\
\hline C $20: 0$ & $0.07 \pm 0.00$ & $0.05 \pm 0.00$ & $0.06 \pm 0.01$ & $0.07 \pm 0.00$ & $* * *$ & - & - & - \\
\hline C $24: 0$ & $0.34 \pm 0.09$ & $0.15 \pm 0.03$ & $0.24 \pm 0.08$ & $0.14 \pm 0.04$ & $* * *$ & $* * *$ & - & - \\
\hline $\mathrm{C} 14: 1$ & $0.07 \pm 0.00$ & $0.08 \pm 0.00$ & $0.07 \pm 0.01$ & $0.10 \pm 0.00$ & - & $*$ & - & - \\
\hline $\mathrm{C} 16: 1$ & $0.88 \pm 0.32$ & $1.29 \pm 0.43$ & $0.87 \pm 0.32$ & $1.07 \pm 0.43$ & - & - & - & - \\
\hline C18:1 cis-11 & $0.70 \pm 0.22$ & $0.74 \pm 0.24$ & $0.69 \pm 0.22$ & $0.81 \pm 0.24$ & - & - & - & - \\
\hline C18 :1 cis-9 & $\begin{array}{l}16.52 \pm \\
7.43\end{array}$ & $20 \pm 7.45$ & $16.51 \pm 7.43$ & $19.49 \pm 7.45$ & - & - & - & - \\
\hline C18:1 trans- 9 & $0.91 \pm 0.24$ & $1.18 \pm 0.20$ & $0.97 \pm 0.24$ & $1.14 \pm 0.20$ & - & - & - & - \\
\hline C20 :1 & $0.06 \pm 0.00$ & $0.06 \pm 0.00$ & $0.08 \pm 0.04$ & $0.11 \pm 0.01$ & - & * & - & - \\
\hline $\begin{array}{l}\text { C18 :2n6 cis- } \\
9\end{array}$ & $3.64 \pm 0.72$ & $3.47 \pm 2.06$ & $2.53 \pm 1.53$ & $4.2 \pm 0.96$ & - & - & - & - \\
\hline
\end{tabular}


Current Trends in Natural Sciences

Vol. 10, Issue 19, pp. 80-88, 2021

https://doi.org/10.47068/ctns.2021.v10i19.010

Current Trends in Natural Sciences (on-line)

ISSN: 2284-953X

Current Trends in Natural Sciences (CD-Rom)

ISSN: 2284-9521

ISSN-L: 2284-9521

ISSN-L: 2284-9521

\begin{tabular}{|c|c|c|c|c|c|c|c|c|}
\hline $\begin{array}{l}\mathrm{C} 18: 2 \mathrm{n} 6 \\
\text { trans-9 }\end{array}$ & $0.33 \pm 0.04$ & $0.23 \pm 0.01$ & $0.24 \pm 0.01$ & $0.29 \pm 0.04$ & *** & - & - & - \\
\hline C18:3n6 & $0.03 \pm 0.02$ & $0.04 \pm 0.01$ & $0.32 \pm 0.06$ & $1.81 \pm 0.09$ & - & $* * *$ & *** & $* * *$ \\
\hline C18:3n3 & $1.34 \pm 0.80$ & $0.12 \pm 0.05$ & $1.74 \pm 1.02$ & $0.15 \pm 0.06$ & $* * *$ & * & $* * *$ & * \\
\hline $\mathrm{C} 20: 2 \mathrm{n} 6$ & $0.15 \pm 0.07$ & $0.2 \pm 0.03$ & $0.23 \pm 0.03$ & $0.18 \pm 0.07$ & - & - & - & - \\
\hline $\mathrm{C} 20: 3 \mathrm{n} 6$ & $0.14 \pm 0.03$ & $0.18 \pm 0.01$ & $0.21 \pm 0.03$ & $0.14 \pm 0.01$ & - & - & - & - \\
\hline $\mathrm{C} 20: 4 \mathrm{n} 6$ & $1.68 \pm 0.40$ & $1.82 \pm 0.36$ & $1.41 \pm 0.23$ & $1.07 \pm 0.09$ & - & $* * *$ & $*$ & - \\
\hline $\mathrm{C} 20: 5 \mathrm{n} 3$ & $0.23 \pm 0.06$ & $0.19 \pm 0.07$ & $0.22 \pm 0.10$ & $0.09 \pm 0.04$ & - & $*$ & $*$ & - \\
\hline $\mathrm{C} 22: 6 \mathrm{n} 3$ & $0.2 \pm 0.04$ & $0.03 \pm 0.04$ & $0.12 \pm 0.02$ & $0.06 \pm 0.02$ & $* * *$ & $* *$ & - & $* *$ \\
\hline SFA & $\begin{array}{l}16.66 \pm \\
7.09\end{array}$ & $25.42 \pm 2.80$ & $14.24 \pm 3.47$ & $24.03 \pm 2.86$ & $* *$ & - & $* *$ & $* * *$ \\
\hline MUFA & $\begin{array}{l}19.11 \pm \\
7.78 \\
\end{array}$ & $23.5 \pm 8.06$ & $19.17 \pm 7.79$ & $23.56 \pm 8.07$ & - & - & - & - \\
\hline PUFA & $7.74 \pm 0.97$ & $6.25 \pm 2.19$ & $6.93 \pm 1.95$ & $6.02 \pm 0.97$ & - & - & - & - \\
\hline n6 & $6 \pm 0.98$ & $5.91 \pm 2.12$ & $4.84 \pm 1.49$ & $5.76 \pm 1.04$ & - & - & - & - \\
\hline n3 & $1.75 \pm 0.80$ & $0.34 \pm 0.08$ & $0.59 \pm 0.24$ & $0.27 \pm 0.09$ & $* * *$ & $* * *$ & - & - \\
\hline$\overline{\Sigma n 6 / \Sigma \mathrm{n} 3}$ & $0.31 \pm 0.16$ & $0.06 \pm 0.01$ & $0.12 \pm 0.03$ & $0.09 \pm 0.02$ & $* *$ & $* * *$ & - & - \\
\hline $\begin{array}{l}\Sigma \mathrm{PUFA} / \Sigma \mathrm{SF} \\
\mathrm{A}\end{array}$ & $\begin{array}{l}0.53 \pm \\
0.20\end{array}$ & $0.24 \pm 0.08$ & $0.31 \pm 0.23$ & $0.25 \pm 0.01$ & - & - & - & - \\
\hline
\end{tabular}

SFA: Saturated fatty acids. MUFA: Monounsaturated fatty acids. PUFA: Polyunsaturated fatty acids. *, $P \leq 0.05$; **, $P \leq 0.01$; ***, $P<0.001$; - : not significant. PCh: Grazing in Chehaima. CCh: Concentrate in Chehaima. PCh: Grazing in Naima. CN: Concentrate in Naima.

Lambs that are feed with concentrate which have exhibited the highest C18: 0 content, has been explained by (Qie et al., 2020), who have found that the concentrated diet increases the C18: 0 content, due to the high saturation of PUFAs; moreover, the total content of SFA reveals a dominance in lambs feed with concentrate, these results are in agreement with those of (Hajji et al., 2016); On the other hand, not only the diet can influence the chemical composition of the meat, but also others factors related to the animal such as breed and age (Erasmus et al., 2017). Concentrated foods are rich in starch, which will increase the intake of FAs by stimulating new ruminal fermentation pathways that increase the saturation of PUFAs (Harmon and Swanson, 2020). Certain supplementary feeds in the ration of small ruminants can modify and reduce the composition of intramuscular SFA and increase those which are unsaturated, by the inclusion of specific oils or oleaginous and marine products (Raes et al., 2004). It is strongly recommended to decrease the total intake of the SFA content, given its harmful effect on human health, while no evidence is taken into consideration as to the effect of saturated fats which vary according to a specific fatty acid for health (Astrup et al., 2019), some of which are beneficial such as lauric acid (C12: 0) which has antimicrobial properties (Nakatsuji et al., 2019), also, the blood concentration of heptadecanoic acid (C17: 0) which does not affect coronary results (O'Neil et al., 2014). Others are not recommended for human health like myristic acid (C14:0) and C16:0 (Nieto and Ros, 2012). The results of the present study indicated that the lambs obtained from the concentrate diet had no significance in the total content of monounsaturated fatty acids (MUFA) than those fed in the steppe ranges, as well as in individual MUFA. These results are in agreement with those of (Moloney et al., 2018) who studied the FA profile of cattle grazed, feed only with pastures, and those fed on concentrate. (Mateo et al., 2017) did not indicate any remarkable difference in the total content of MUFA and on individual monounsaturated FA in small ruminants fed with the concentrate in stable or grazing in 
the rangelands during the spring period. In fact, it could be related to the phenomenon of remanence, according to tests carried out by (Aldai et al. 2011) to study the effects of feeding strategies on the lipid fraction of lambs, revealed that after changes in the ration by substituting grazing of the grass by the concentrated feed, half of the FAs were partially changed from the total fat one month after of the experiment, however, after 2 months were gone completely. Contrary to the results of the present study, (Steffen et al., 2018) revealed that a high content of FA C18: 1 can cause the risk of developing cardiovascular diseases, which does not only come from the diet, but it could be affected by other factors that regulate its plasma concentration, as its de novo synthesis from C18: 0 by intervention of Stearoyl-CoA desaturase-1 (SCD1). In the two regions, no difference was observed in the total content of PUFAs; these results are similar to those found by (Panea et al., 2011), in contrast to (Lobon et al., 2019), who found that the grass-fed lambs having high levels of total PUFAs compared to those from concentrate. For both regions, the most dominant FAs in the intramuscular lipid fraction of pasture lambs are $\mathrm{C} 18: 3 \mathrm{n} 3$ followed by $\mathrm{C} 18$ : 2n6 cis-9, C20: 4n6, C20: 5n3, and C22: $6 \mathrm{n} 3$ compared to those from concentrate, however, the lambs in the concentrate diet had the most dominant FA in their intramuscular fat, C18: 3n6 followed by C20: $4 \mathrm{n} 6$ in lambs from Chehaima compared to those from the pasture of Naima. The feed can provide small ruminants with FA in varying proportions, the composition of which feeds concentrated in PUFA is dominated by LA which is the precursor of PUFALC $\mathrm{n}-6$, whereas, pastures contribute to the high intakes of ALA, which is the precursor of PUFALC n-3, where the biohydrogenation of these essential FAs is around $80 \%$ and $92 \%$ for LA and ALA respectively. This process is highly dependent on the rate of passage and the residence time in the rumen (Dugan et al., 2018). LA n-6 and ALA n-3 undergo elongation and desaturation in ruminant tissues by metabolism in n-6 (arachidonic acid (C20: 4 n-6)) and n-3 (eicosapentaenoic acid (C20: 5 n-3), docosapentaenoic acid (C22: 5n-3) and docosahexaenoic acid (C22: 6 n-3) (Jambrak and Skevin, 2017). The fatty acid enzymes (SCD 1) and (SCD 2) often interfere with ALA to the detriment of LA, while a diet rich in LA can interfere with the process of conversion of ALA to EPA, DPA n-3, and DHA; this process of elongation and desaturation is slow, considered inefficient compared to the direct absorption of PUFALCs (ALA, EPA, and DHA) from food which can escape biohydrogenation in the rumen, because they are protected by metabolites secondary constituted in the grass, which can play a protective role against the saturation of PUFALCs in the rumen (Vahmani et al., 2020). The same results were found by (Liang et al., 2017) in the milk of cattle in different regions, indicating that the C18: 3 content is higher in grass-fed animals, while C18: 2 is dominant in those fed with concentrate, however, the latter is susceptible to be oxidized. In this study, the intramuscular lipid fraction of grass-based diet lambs was lower in C20: 4 n6 which is explained by its synthesis from its precursor C18: 2 n-6. The appearance of PUFALC C22: 6 n-3 which had high values observed in pasture lambs compared to those in concentrate, was due according to (Díaz et al., 2011) to the elongation and desaturation of C18: 3 n-3. Feeding practices in free ranges advantageously improve the FA profile; on the other hand, the variability of the individual plants that characterize and dominate in these different rangelands can affect the capacity and retention time of FA in the rumen, thus their composition in antioxidants which protect PUFAs, lead to a considerable accumulation of these FAs, in particular, C18: 3n3, the precursor of C22: $6 \mathrm{n} 3$ (Elgersma, 2015). Recent simultaneous studies have described lipogenesis in the rumen, as a function of biohydrogenation, which is conditioned by the selection of ruminal microflora depending on the type of food, the variety of plant species, the amount of fiber and starch consumed by the ruminant which can decrease ruminal $\mathrm{pH}$, which inhibits the activity of certain bacteria and 
stimulates the activity of a new bacterial population, and consequently, a modification of ruminal metabolism of FA (Dewanckele et al., 2020 ; Frutos et al., 2020 ; Huyen et al., 2020). A high content of PUFA n-3, in particular PUFALC such as EPA, is inversely correlated with the prevalence in young people suffering from depression (Berger et al., 2017). The n-6 content did not show any difference in all lambs; however, the n-3 content was higher in the lambs that grazed the grass, same results were found by (Belhaj et al., 2020) in the lambs and by (Aldai et al., 2011) in cattle. The values of the ratio n- $6 /$ n-3 are correctly balanced and correspond to the nutritional recommendations of the (British Department of Health, 1994), which have prescribed a value that must not exceed 4. These results are similar to (Alfaia et al., 2009), who found a ratio that suits the recommendations in Pasture lambs, whereas, in lambs from the concentrated diet, they had a ratio that exceeded 4. The highest $\Sigma$ PUFA / $\Sigma$ SFA feed ratio was found in lambs from Chehaima pastures, at a value of (0.53). According to (McAfee et al., 2010), the desired $\Sigma$ PUFA / $\Sigma$ SFA ratio, must be greater than 0.4. However, the values of this ratio in lambs feed with concentrate $(0.24)$ from Chehaima, as well as those from the Naima region (pasture: 0.31 and concentrate: 0.25) are not close enough to the value desired, this could be due to the degree of saturation of PUFAs by the process of biohydrogenation caused by ruminal bacteria. These values agree with similar results that were reported by (Majdoub et al., 2015; D’Alessandro et al., 2018).

\section{CONCLUSIONS}

The results obtained in the present experiment suggest that the meat of lambs having access to pasture in the spring period have a desirable intramuscular fatty acid composition for human health; this diet generated a high intake of PUFAs such as ALA, EPA and DHA. The FA profile of pasture lambs in the Chehaima region is characterized by a dominance of C18: 3n3. Little difference in PUFALC was reported compared to those from the concentrate diet, with high content of C18: 2n6 cis-9; the latter according to the literature is dominant in lambs fed the concentrate, probably due to the phenomenon of remanence where the lambs spent a short time grazing on the grasses in the steppe. In the Naima region, dominant FAs for pastures lambs are the C18: $3 \mathrm{n} 3$, followed by $\mathrm{C} 20$ : $4 \mathrm{n} 6$ and $\mathrm{C} 20$ : $5 \mathrm{n} 3$; for those in the concentrate feed, we found the C18: $2 \mathrm{n} 6$ cis-9 followed by C18: 3n6. In both regions, the total SFA content was higher in the lambs from the concentrate diet, with individual SFA dominated by C 16: 0 and C 18: 0. Regarding the nutritional ratios, n-6 / n-3 in both diets resulted in favorable values for human health, the ratio $\Sigma$ PUFA / $\Sigma$ SFA for the two diets did not reach the values recommended by nutritionists, excepted for pasture lambs in the Chehaima region; this is explained by the saturation rate of PUFAs in the rumen.

We can say at the end, the more lambs are allowed to graze in steppe, and for long periods, the more that it will bring to their tissues to have a lower SFA content, and more beneficial, with a very rich accumulation of PUFA. Further analyzes should be carried out to determine to what extent the impact of dietary supplements can alter the lipid fraction of the meat of lambs that graze in steppe zones, and that obtained by those fed the concentrated feed.

\section{REFERENCES}

Aldai, N., Dugan, M. E. R., Kramer, J. K. G., Martínez, A., López-Campos, O., Mantecón, A. R., and Osoro, K. (2011). Length of concentrate finishing affects the fatty acid composition of grass fed and genetically lean beef: an emphasis on trans-18:1 and conjugated linoleic acid profiles. Animal, 5(10), 1643-1652. doi:10.1017/s1751731111000607.

Alfaia, C. P. M., Alves, S. P., Martins, S. I. V., Costa, A. S. H., Fontes, C. M. G, A et al (2009). Effect of the feeding system on intramuscular fatty acids and conjugated linoleic acid isomers of beef cattle, with emphasis on their nutritional value and discriminatory ability. Food Chemistry, 114, 939-946. 


\section{Current Trends in Natural Sciences}

Vol. 10, Issue 19, pp. 80-88, 2021

https://doi.org/10.47068/ctns.2021.v10i19.010

Current Trends in Natural Sciences (on-line)

ISSN: 2284-953X

Current Trends in Natural Sciences (CD-Rom)

ISSN: 2284-9521

ISSN-L: 2284-9521

ISSN-L: 2284-9521

Amin, A.B., Mao, S. (2020) Influence of yeast on rumen fermentation, growthperformance and quality of products in ruminants: A review. Animal Nutrition Journal, https://doi.org/10.1016/j.aninu.2020.10.005.

Angeles-Hernandez, J. C., Vieyra Alberto, R., Kebreab, E., Appuhamy, J. A. D. R. N., Dougherty, H. C., CastelanOrtega, O., and Gonzalez-Ronquillo, M. (2020). Effect of forage to concentrate ratio and fat supplementation on milk composition in dairy sheep: A meta-analysis. Livestock Science, 238, 104069. doi:10.1016/j.livsci.2020.104069.

Astrup, A., Bertram, H. C., Bonjour, J.-P., de Groot, L. C., de Oliveira Otto, M. C., Feeney, E. L., Soedamah-Muthu, S. S. (2019). WHO draft guidelines on dietary saturated and trans fatty acids: Time for a new approach? 366, 14137.

Belhaj, K., Mansouri, F., Sindic, M., Taaifi, Y., Boukharta, M., Serghini-Caid, H., and Elamrani, A. (2020). Effect of the concentrate-based finishing on the proximate composition, organoleptic quality and fatty acids profile of the Beni-Guil sheep meat. E3S Web of Conferences, 183, 04001. doi:10.1051/e3sconf/202018304001.

Berger, M. E., Smesny, S., Kim, S.-W., Davey, C. G., Rice, S., Sarnyai, Z., Schlögelhofer, M., Schäfer, M.R., Berk, M., McGorry, P.D., Amminger, G. P. (2017). Omega-6 to omega-3 polyunsaturated fatty acid ratio and subsequent mood disorders in young people with at-risk mental states: a 7-year longitudinal study. Translational Psychiatry, 7(8), e1220. doi:10.1038/tp.2017.190.

British Department of Health (1994). Nutritional aspects of cardiovascular disease. Report on Health and Social Subjects No. 46. London: HMSO.

Berrighi, N., Belkacemi, L., Bouderoua, k., Santaella, M., Gaspar, R., Nieto, G. (2017). Fatty acids composition and sensory properties of lamb meat fed on steppe and highland pastures. Asian J. Anim. Sci., 11, 88-95.

Budimir, K., Mozzon, M., Toderi, M., D’Ottavio, P., and Trombetta, M. F. (2020). Effect of Breed on Fatty Acid Composition of Meat and Subcutaneous Adipose Tissue of Light Lambs. Animals, 10(3), 535. doi:10.3390/ani10030535.

Cividini, A., Simčič, M., Stibilj, V., Vidrih, M., and Potočnik, K. (2018). Changes in fatty acid profile of Bovec sheep milk due to different pasture altitude. Animal, 1-8. doi:10.1017/s1751731118002598.

D’Alessandro, A. G., Maiorano, G., Casamassima, D., Martemucci, G., (2018). Fatty acid composition and vitamin E of meat as influenced by age and season of slaughter in Mediterranea light lamb. Small Ruminant Research, https://doi.org /10.1016/j. smallrumres.2018.11.019.

Daley, C. A., Abbott, A., Doyle, P. S., Nader, G. A., and Larson, S. (2010). A review of fatty acid profiles and antioxidant content in grass-fed and grain-fed beef. Nutrition Journal, 9(1). doi:10.1186/1475-2891-9-10.

Dewanckele, L., Toral, P. G., Vlaeminck, B., and Fievez, V. (2020). Invited review: Role of rumen biohydrogenation intermediates and rumen microbes in diet-induced milk fat depression: An update. Journal of Dairy Science, 103(9), 7655-7681. doi:10.3168/jds.2019-17662.

De Smet, S., Raes, K., Demeyer, D., (2003). Meat fatty acid composition as affected by genetics. Anim. Res., in press.

Dias, C. B., Amigó, N., Wood, L. G., Mallol, R., Correig, X., and Garg, M. L. (2017). Improvement of the omega 3 index of healthy subjects does not alter the effects of dietary saturated fats or n-6PUFA on LDL profiles. Metabolism, 68, 11-19. doi:10.1016/j.metabol.2016.11.014.

Diaz, M.T., Álvarez, I., De La Fuente, J., Sañudo, C., Campo, M.M., Oliver, M.A., Font I Furnols, M., Montossi, F., San Julián, R., Nute, G.R. , Cañeque, V. (2005). Fatty acid composition of meat from typical lamb production systems of Spain, United Kingdom, Germany and Uruguay. Meat Science, 71, 256-263.

Díaz, M. T., Cañeque, V., Sánchez, C. I., Lauzurica, S., Pérez, C., Fernández, C., Álvarez, I., De la Fuente, J. (2011). Nutritional and sensory aspects of light lamb meat enriched in $\mathrm{n}-3$ fatty acids during refrigerated storage. Food Chemistry, 124(1), 147-155. doi:10.1016/j.foodchem.2010.05.117.

Dugan, M. E. R., Mapiye, C., and Vahmani, P. (2018). Polyunsaturated Fatty Acid Biosynthesis and Metabolism in Agriculturally Important Species. Polyunsaturated Fatty Acid Metabolism, 61-86. doi:10.1016/b978-0-12811230-4.00004-1.

Elgersma, A. (2015). Grazing increases the unsaturated fatty acid concentration of milk from grass-fed cows: A review of the contributing factors, challenges and future perspectives. European Journal of Lipid Science and Technology, 117(9), 1345-1369. doi:10.1002/ejlt.201400469.

Erasmus, S. W., Muller, M., and Hoffman, L. C. (2017). Authentic sheep meat in the European Union: Factors influencing and validating its unique meat quality. Journal of the Science of Food and Agriculture, 97(7), 19791996. doi:10.1002/jsfa.8180.

Frutos, P., Hervás, G., Natalello, A., Luciano, G., Fondevila, M., Priolo, A., and Toral, P. G. (2020). Ability of tannins to modulate ruminal lipid metabolism and milk and meat fatty acid profiles. Animal Feed Science and Technology, 114623. doi:10.1016/j.anifeedsci. 2020.114623. 


\section{Current Trends in Natural Sciences}

Vol. 10, Issue 19, pp. 80-88, 2021

https://doi.org/10.47068/ctns.2021.v10i19.010

Current Trends in Natural Sciences (on-line)

ISSN: 2284-953X

Current Trends in Natural Sciences (CD-Rom)

ISSN: 2284-9521

ISSN-L: 2284-9521

ISSN-L: 2284-9521

Hajji, H., Joy, M., Ripoll, G., Smeti, S., Mekki, I., Gahete, F. M., Mahouachi, M., Atti, N. (2016). Meat physicochemical properties, fatty acid profile, lipid oxidation and sensory characteristics from three North African lamb breeds, as influenced by concentrate or pasture finishing diets. Journal of Food Composition and Analysis, 48, 102-110. doi:10.1016/j.jfca.2016.02.011.

Harmon, D. L., Swanson, K. C. (2020). Review: Nutritional regulation of intestinal starch and protein assimilation in ruminants. Animal, 14:S1, pp s17-s28. doi:10.1017/S1751731119003136.

Huyen, N. T., Verstegen, M. W. A., Hendriks, W. H., and Pellikaan, W. F. (2020). Sainfoin (Onobrychis viciifolia) silage in dairy cow rations reduces ruminal biohydrogenation and increases transfer efficiencies of unsaturated fatty acids from feed to milk. Animal Nutrition. doi:10.1016/j.aninu.2020.05.001.

Jambrak, A. R., Škevin, D. (2017). Lipids. Nutraceutical and Functional Food Components, $103-128$. doi:10.1016/b978-0-12-805257-0.00004-1.

Jutzeler van Wijlen, R. P., and Colombani, P. C. (2010). Grass-based ruminant production methods and human bioconversion of vaccenic acid with estimations of maximal dietary intake of conjugated linoleic acids. International Dairy Journal, 20(7), 433-448. doi:10.1016/j.idairyj.2010.01.008.

Klir, Ž., Antunović, Z., Halas, V., Domaćinović, M., Šperada, M., Novoselec, J. (2012): Modeling the fatty acid composition of lamb meat by feeding. Meso: prvi hrvatski ča sopis o mesu, 14, 43-49.

Liang, K. H., Zhao, Y., Han, J., Liu, P., Qiu, J., Zhu, D. Z., et al. (2017). Fatty acid composition, vitamin A content and oxidative stability of milk in China. Journal of Applied Animal Research, 46(1), 1-6.

Lobon, S., Joy, M., Sanz, A., Alvarez-Rodriguez, J., and Blanco, M. (2018). The fatty acid composition of ewe milk or suckling lamb meat can be used to discriminate between ewes fed different diets. Animal Production Science. doi:10.1071/an18082.

Luciano, G., Biondi, L., Pagano, R. I., Scerra, M., Vasta, V., López-Andrés, P., Valenti, B., Lanza, M., Priolo, A., and Avondo, M., (2012). The restriction of grazing duration does not compromise lamb meat colour and oxidative stability. Meat Science, 92, 30-35.

Majdoub - Mathlouthi, L., Said, B., Kraiem, K., (2015). Carcass traits and meat fatty acid composition of Barbarine lambs reared on rangelands or indoors on hay and concentrate. Animal, 9:12, 2065-2071.

McAfee, A. J., McSorley, E. M., Cuskelly, G. J., Moss, B. W., Wallace, J. M. W., Bonham, M. P., and Fearon, A. M. (2010). Red meat consumption: An overview of the risks and benefits. Meat Science, 84(1), 1-13. doi:10.1016/j.meatsci.2009.08.029.

Mateo, L., Delgado, P., Ortuño, J., and Bañón, S. (2017). Maternal grazing on stubble and Mediterranean shrubland improves meat lipid profile in light lambs fed on concentrates. Animal, 12(07), 1547-1554. doi:10.1017/s1751731117003263.

Moloney, A., O'Riordan, E., Schmidt, O., and Monahan, F. (2018). The fatty acid profile and stable isotope ratios of C and $\mathrm{N}$ of muscle from cattle that grazed grass or grass/clover pastures before slaughter and their discriminatory potential. Irish Journal of Agricultural and Food Research, 57, 84-94. doi:10.2307/26555014.

Nakatsuji, T., Kao, M. C., Fang, J.-Y., Zouboulis, C. C., Zhang, L., Gallo, R. L., and Huang, C.-M. (2009). Antimicrobial Property of Lauric Acid Against Propionibacterium Acnes: Its Therapeutic Potential for Inflammatory Acne Vulgaris. Journal of Investigative Dermatology, 129(10), 2480-2488. doi:10.1038/jid.2009.93.

Nieto, G., and Ros, G. (2012). Modification of Fatty Acid Composition in Meat Through Diet: Effect on Lipid Peroxidation and Relationship to Nutritional Quality - A Review. Lipid Peroxidation. doi:10.5772/51114.

Nguyen, D. V., Malau-Aduli, B. S., Cavalieri, J., Nichols, P. D., and Malau-Aduli, A. E. O. (2018). Supplementation with plant-derived oils rich in omega-3 polyunsaturated fatty acids for lamb production . Veterinary and Animal Science. doi:10.1016/j.vas.2018.08.001.

Nuernberg, K., Dannenberger, D., Nuernberg, G., Ender, K., Voigt, J., Scollan, N. D., Wood, J.D., Nute, G.R., Richardson, R. I. (2005). Effect of a grass-based and a concentrate feeding system on meat quality characteristics and fatty acid composition of longissimus muscle in different cattle breeds. Livestock Production Science, 94(12), 137-147. doi:10.1016/j.livprodsci.2004.11.036.

O’Neil, A., and Itsiopoulos, C. (2014). Association of Dietary, Circulating, and Supplement Fatty Acids with Coronary Risk. Annals of Internal Medicine, 161(6), 458. doi:10.7326/114-5018-10.

Panea. B., Carrasco, S., Ripoll, G., Joy, M., (2011). Diversification of feeding systems for light lambs: sensory characteristics and chemical composition of meat. Spanish Journal of Agricultural Research, 9(1), 74-85. 


\section{Current Trends in Natural Sciences}

Vol. 10, Issue 19, pp. 80-88, 2021

https://doi.org/10.47068/ctns.2021.v10i19.010

Current Trends in Natural Sciences (on-line)

ISSN: 2284-953X

Current Trends in Natural Sciences (CD-Rom)

ISSN: 2284-9521

ISSN-L: 2284-9521

ISSN-L: 2284-9521

Pannier, L., Gardner, G. E., O’Reilly, R. A., and Pethick, D. W. (2018). Factors affecting lamb eating quality and the potential for their integration into an MSA sheepmeat grading model. Meat Science, 144, $43-52$. doi:10.1016/j.meatsci.2018.06.035.

Ponnampalam, E. N., Hopkins, D. L., and Jacobs, J. L. (2018). Increasing omega-3 levels in meat from ruminants under pasture-based systems. Revue scientifique et technique, 37(1), 57-70. https://doi.org/10.20506/rst.37.1.2740.

Prache, S., Martin, B., and Coppa, M. (2019). Review: Authentication of grass-fed meat and dairy products from cattle and sheep. Animal, 1-10. doi:10.1017/s1751731119002568.

Qie, M., Zhang, B., Li, Z., Zhao, S., and Zhao, Y. (2020). Data fusion by ratio modulation of stable isotope, multielement, and fatty acids to improve geographical traceability of lamb. Food Control, 107549. doi:10.1016/j.foodcont.2020.107549.

Raes, K., De Smet, S., and Demeyer, D. (2004). Effect of dietary fatty acids on incorporation of long chain polyunsaturated fatty acids and conjugated linoleic acid in lamb, beef and pork meat: a review. Animal Feed Science and Technology, 113(1-4), 199-221. doi:10.1016/j.anifeedsci.2003.09.001.

Rabah, H. F., Niar, A., Abdalli, W. (2019). Composition of intramuscular fatty acids from sheep living in Steppe zones, TIARET region, ALGERIA. Adv. Biores., Vol 10 [5]. DOI: 10.15515/abr.0976-4585.10.5.1218.

Ružić-Muslić, D., Bijelić, Z., Petrovic, P.M., Petrović, M.M., Pantelićv., Perišićp., Caro-Petrovic, V. (2012). Some aspects of improvement of grassland production for grazing of sheep. Biotechnology in Animal Husbandry, 28, 2, 283-295.

Saini, R. K., and Keum, Y.-S. (2018). Omega-3 and omega-6 polyunsaturated fatty acids: Dietary sources, metabolism, and significance - A review. Life Sciences, 203, 255-267. doi:10.1016/j.lfs.2018.04.049.

Steffen, B. T., Duprez, D., Szklo, M., Guan, W., and Tsai, M. Y. (2018). Circulating oleic acid levels are related to greater risks of cardiovascular events and all-cause mortality: the Multi-Ethnic Study of Atherosclerosis. Journal of Clinical Lipidology. doi:10.1016/j.jacl.2018.08.004.

Tor, M., Estany, J., Francesch, A., Cubiló, M. D., (2005). Comparison of fatty acid profiles of edible meat, adipose tissues and muscles between cocks and capons. Animal Research, 54, 413- 424.

Vahmani, P., Ponnampalam, E. N., Kraft, J., Mapiye, C., Bermingham, E. N., Watkins, P. J., Dugan, M. E. R. (2020). Bioactivity and health effects of ruminant meat lipids. Invited Review. Meat Science, 108114. doi:10.1016/j.meatsci.2020.108114.

Wood, J. D., Richardson, R. I., Nute, G. R., Fisher, A. V., Campo, M. M., Kasapidou, E., Enser, M. (2004). Effects of fatty acids on meat quality: a review. Meat Science, 66(1), 21-32. https://doi.org/10.1016/S03091740(03)00022-6. 